\section{ECONOMICS}

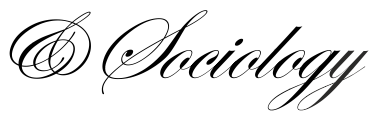

Pérez González, M. C., \& Valiente Palma, L. (2019). Territory and cooperativism: A spatial analysis of the Spanish region of Andalusia. Economics and Sociology, 12(2), 265-283. doi:10.14254/2071-789X.2019/12-2/16

\title{
TERRITORY AND COOPERATIVISM: A SPATIAL ANALYSIS OF THE SPANISH REGION OF ANDALUSIA
}

\author{
María del Carmen Pérez \\ González, \\ University of Cadiz, \\ Cádiź, Spain \\ E-mail: maricarmen.perez@uca.es
}

Lidia Valiente Palma, University of Cadiz,

Cádiz, Spain

E-mail:lidia.valiente@uca.es

Received: December, 2018

1st Revision: March, 2019

Accepted: May, 2019

DOI: $10.14254 / 2071-$

789X.2019/12-2/16

JEL Classification: C21, O18, P12, P13, R12

\begin{abstract}
This study seeks to identify the behavior of cooperative societies in Andalusia, as well as the environments in which their greater relative importance is evident. The weight of cooperative societies is significantly greater in Andalusia as compared to the rest of Spain. These organizations are noteworthy for acting under social, economic and environmental principles and values, and represent a potential opportunity for the region. The methodology applied for this purpose consists of spatial analysis using descriptive graphing techniques and application of spatial autocorrelation. Among the results obtained, a significant finding is these organizations' defined behavior as opposed to that of mercantile or traditional businesses. In mapping the weight of cooperativism in Andalusia, this study enables a deeper understanding that could lead to improved design and execution of general and specific territorial policies, and with a greater guarantee of success.
\end{abstract}

Keywords: territory, cooperative societies, Andalusia, spatial autocorrelation, exploratory spatial data analysis (ESDA)

\section{Introduction}

Cooperative societies, as core organizations of the social economy are designed to reinforce the link between economies and societies and the concept of "local" (Draperi, 2014). These organizations are characterized by a number of guiding principles and values, among which can be found commitment to the local community, as evidenced by the activities they carry out, such as social reintegration or promotion of social and collective enterprise (Novkovic, 2008); the response to new social needs via new sources of employment (Vilallonga, 2002); or creation of sustainable employment contributing to reduction in social inequalities in the country (Burgués, Martin \& Santa Cruz, 2013).

To the aforementioned it must be added that the decision to focus this study on the autonomous community of Andalusia, a region located in the south of Spain, stems from two main issues: on the one hand, the considerable relative lag suffered by the region with respect to the rest of the country, evident in such indicators as the at-risk-of-poverty rate $(35.4 \%$ according to the 2016 Living Conditions Survey [Encuesta de Vidas Laborales]) or the rate of unemployment (27\% in the first quarter of 2017 according to the Economically Active Population Survey [Encuesta de Población Activa]); on the other hand, the presence of 
significant cooperativism in this community (19\% of cooperatives and $18 \%$ of the employment they produce nationwide are found in Andalusia).

It is also worth noting that interregional disparities found in Spain are compounded by those existing within the region of Andalusia itself. Such inequalities (social, economic, environmental etc.) occur not only with respect to other Spanish autonomous communities but also at the intraregional level in Andalusia, with important gaps occurring, for example, between urban and rural territories. Numerous studies (Torres \& Ojeda, 2004; Caravaca, González \& Mendoza, 2007; Méndez, Melero \& Calatrava, 2008; Fernández et al., 2007; Zoido et al., 2009; Pita \& Pedregal, coords. 2011; Sánchez, Gallardo \& Ceña, 2014; among others) have revealed the territorial diversity in Andalusia from various perspectives. As such, the deep-seated nature of cooperative societies in the region, their guiding principles and values, the socioeconomic situation of Andalusia and its territorial diversity, and the existence of a significant cooperative movement in the region - as an opportunity for having impact on the area - have been the motivating factors behind this study.

Following the aforementioned premise, analysis of spatial autocorrelation has been applied - after deeper exploration of the weight of cooperativism and of mercantile businesses using cartograms and other descriptive analyses - for the purpose of identifying the behavior of cooperative societies in the region and the environments in which greater relative importance is given to these societies. This has been done in order to show the relationship among territory, economy and society and, more specifically, the rooting of these organizations in the environment in which they carry out their activities.

These analyses are carried out from the comparative perspective with respect to the conventional business sector represented by mercantile businesses, that is to say, by public limited companies and limited liability companies. Specifically, the working hypothesis is as follows:

Due to the significant link between cooperatives and the environment in which they do their work, and given the territorial diversity of Andalusia, the behavior of these organizations in the region lacks homogeneity. In other words, the weight of cooperativism does not follow random distribution but rather responds to a pattern of behavior that is related to territorial diversity.

From the public policy perspective, the act of comparing them with the conventional business sector is motivated by the need to grant (or not to grant) cooperatives treatment, specific and different from the rest of the business sector and which takes into account their distinct behavior in the region. On the contrary, a failure to provide for this heterogeneity might prevent general policies designed to drive cooperativism from yielding the desired effects in their application.

In order to achieve the aforementioned objective and after providing an introduction which outlines the current interest in the topic, the structure of this study consists of the second section which presents spatial analysis of cooperativism as compared to the rest of mercantile or conventional businesses, detailing the methodology used and the results and discussion derived from its application, followed by a section with the final considerations, conclusions and research contributions. A prominent finding among the results obtained is, on the one hand, the distinct productive structure of the geographical areas in which cooperativism has a significant weight and, on the other hand, the cooperative movement's greater degree of heterogeneity in the region of Andalusia. This study therefore contributes to deeper understanding of cooperative societies and the environments in which their presence is significant as it is shown on the example of the autonomous community of Andalusia. 


\section{Spatial analysis of cooperativism in contrast with mercantile businesses}

The goal of the study has been achieved bearing in mind that, according to Anselin (1999), common patterns of behavior may emerge from individual interactions in space, giving rise to collective socioeconomic dynamics in a given territory. Along these same lines, in addition to identifying the differences among cooperatives and the conventional business sector, the existence of these patterns and their differences with other territorial spaces within the region of Andalusia has been determined.

As such, the analysis thus described identifies the places where these patterns occur, which may be interpreted as environments in which factors favoring the presence of cooperative societies might exist. Likewise, it identifies other places less favorable to cooperativism, which should be taken into consideration when it comes to general and specific strategies for their revitalization.

As the object under study in this work, the autonomous community of Andalusia is noteworthy for its territorial diversity in the social and economic terms previously mentioned, with a large portion of its territory considered to be rural. This should be borne in mind when applying strategies and policies for regional development and, for this reason, both the stated goal of the study and the methodology for achieving it are of particular interest.

\subsection{Methodology}

An exploratory spatial data analysis (ESDA) was carried out in order to achieve study's aims. This methodology allows for the identification of variable patterns of spatial association or concentration with respect to which their location in space proves decisive in analyzing their behavior. In other words, an ESDA may be defined as "a set of techniques for describing and visualizing spatial distributions, identifying atypical spatial locations or spatial outliers, discovering patterns of spatial association, clusters or hot spots, and suggesting spatial regimes or other forms of spatial heterogeneity." (Anselin, 1998:4). In this sense, spatial analysis graphing techniques are used for the purpose of visualizing the distribution of cooperativism in Andalusia, as compared to mercantile or conventional businesses.

In order to achieve this, consideration is made of the contiguity and geographical proximity of the variables under analysis, suggesting the existence of interdependency among neighboring areas, with closer areas having a higher degree of reciprocal influence than remote areas (Amara, 2009). In keeping with Cliff and Ord (1981), the following question is posed: is the spatial structure of a variable significant, and must its behavior be therefore interpreted? And if this is the case, is the spatial structure of cooperativism significant, when measured as a proportion of total businesses?

Given the existence of literature on the idea that cooperativism is related to the working environment (García-Gutiérrez, 1999; Buendía \& García, 2003; Coque, 2005; Mozas \& Bernal, 2006; Cuñat \& Coll, 2007; Puentes \& Velasco, 2009; Calvo \& González, 2011; Demoustier, 2011; Draperi, 2014; Guzmán, Santos \& Barroso, 2016; Pérez \& Valiente, 2017), the aforementioned hypothesis is proposed that the proportion of these societies (out of the total number of organizations) does not follow a random distribution in Andalusia but rather responds to a pattern of behavior that is related to territorial diversity.

Based on the aforementioned, the existence or absence of spatial autocorrelation was determined for the proportion of cooperatives in Andalusia (and, on the other hand, for mercantile businesses, in order to establish comparative analyses); in other words, analyzing whether there is a relationship between what occurs at a given point in space - in this case a municipality - and what occurs at other points (other municipalities) (Anselin, 1988), with 
such a relationship possibly due to the socioeconomic and territorial characteristics found in the corresponding environments. Specifically, the level of dependence is measured (in this case, that of a municipality) with respect to those nearby.

Spatial autocorrelation determines the degree to which activities in one territory are similar to those of nearby territories (Goodchild, 1987) and may in turn be positive or negative. Positive spatial autocorrelation takes place where high (or low) values of a random variable are distributed in groups in space, i.e. they show similar behavior; on the other hand, negative spatial autocorrelation occurs when nearby territorial units show highly contrasting values (Cliff and Ord, 1981).

The existence of spatial autocorrelation is contrasted using the Moran's I (1948) measure, which establishes the absence of spatial autocorrelation or the random distribution of the variable in the different areas under study as a null hypothesis. This is expressed as follows:

$$
I=\frac{n}{S_{0}} \frac{\sum_{i=j}^{n} \sum_{j=1}^{n} w_{i j}\left(y_{i}-\bar{y}\right)\left(y_{j}-\bar{y}\right)}{\sum_{i=1}^{n}\left(y_{i}-\bar{y}\right)^{2}}, i \neq j,
$$

where $y_{i}$ is the variable analyzed in territory $i, \bar{y}$ the average of the $y$ variable, $w_{i j}$ the element or weighted coefficient of the $\mathrm{W}$ matrix -known as a matrix of contiguity or geographic weight matrix- that determines which municipalities are neighbors, $S_{0}$ the sum of the spatial weights, that is to say $S_{0}=\sum_{i=j}^{n} \sum_{j=1}^{n} w_{i j}$ for $i \neq j$, and $n$ is the same sample size. The $\mathrm{W}$ matrix is formed of one and zero values, according to the existence or absence of contiguity between given geographical areas, such that $\mathrm{w}_{\mathrm{ij}}=1$ where regions $i$ and $j$ share a common border, and $w_{i j}=0$ where they do not. In this case, Queen-type contiguity has been considered (meaning that two municipalities are neighbors or contiguous where they have a point of space in common) (Moreno \& Vayá, 2000) with first-order spatial lag.

This measurement $(I)$ is standardized (Duncan, 1991): $Z(I)=\frac{I-E(I)}{\sqrt{V(I)}} \sim \mathrm{N}(0,1)$, where $E(I)$ is the el mean value of $I$, and $V(I)$ is its standard deviation. Spatial autocorrelation is confirmed where the value of $Z(I)$ is statistically significant.

Moran's I may vary between 1 and -1 , where 0 indicates the absence of spatial autocorrelation (random distribution of the variable), i.e. of a defined pattern of behavior, whilst values close to -1 or 1 signify negative or positive spatial autocorrelation, respectively.

In addition to this global measure of spatial autocorrelation, there are Local Indicators of Spatial Association (LISA) that allow for clusters or spatial groupings of the variable under study to be obtained. This signifies the possibility of obtaining environments favoring (or not favoring) cooperativism based on the grouping of a given number of municipalities that may share economic or inter-territorial synergies. The local Moran's I calculated for each municipality in the geographic space of Andalusia is used for obtaining these clusters. This indicator is defined as follows (Anselin, 1995):

$$
I_{i}=\frac{\left(y_{i}-\bar{y}\right)}{\sum_{i=1}^{n}\left(y_{i}-\bar{y}\right)^{2} / n} \sum_{j=1}^{n} w_{i j}\left(y_{j}-\bar{y}\right) \text { for } i \neq j
$$

In this case, what occurs in $i$ with respect to the reference variable is a function of the values that it taken by the latter in $j$, its neighboring or nearby locations. In other words, an attempt is made to calculate the local Moran's I for every municipality, determining the degree to which each is similar to its neighbors. This local measurement is also standardized in such a way that if $\mathrm{Z}\left(I_{i}\right)$ is statistically significant, the existence of a given cluster or spatial grouping may be confirmed. The resulting map shows the groupings produced where a municipality presents a high (or low) value for the variable that is close to those 
municipalities also having high (or low) values (areas with similar values) and atypical or extreme values (areas whose values differ amongst themselves) (Longley \& Tobon, 2004).

The advantage of the local Moran's I indicator with respect to the global Moran's I is that, in addition to determining whether or not spatial autocorrelation exists, it allows us to identify where the said autocorrelation is located. On the other hand, one of the limitations worth noting with regard to the local Moran's I indicator is that it identifies only high, low and atypical value clusters and does not establish the degree of autocorrelation by means of values (Anselin, 1995).

With respect to the data used in carrying out this spatial analysis, the study has worked with the variables "cooperatives as a proportion of total businesses" and "mercantile businesses as a proportion of total businesses", expressed in percentages, for the purpose of being able to establish comparisons and determine whether cooperatives truly show a distinct pattern of behavior. In calculating these variables, the following data were analyzed: Andalusia municipalities $(n=770)$, number of cooperatives, number of public limited companies and limited liability companies (mercantile businesses or companies) and total number of businesses, available in the Directory of Businesses and Establishments [Directorio de Empresas y Establecimientos] of the Andalusia Institute of Statistics and Cartography [Instituto de Estadistica y Cartografía de Andalucía and hereinafter IECA, its Spanish abbreviation] for 2015. In addition to the totals, data was obtained by productive sector.

However, for the primary sector, the proxy variable used was the number of agricultural businesses legally registered as cooperative societies on the one hand, and legally registered as a public limited company or a limited liability company on the other, based on the 2009 Agricultural Census [Censo Agrario] available from IECA. This is due to the limitation presented by the data from the Directory of Businesses and Establishments, which does not count organizations without legal establishment.

In addition to the aforementioned, the index of productive specialization for municipalities has been calculated in order to establish relationships between spatial patterns of behavior and the productive activity in which these municipalities are specialized. This index has been calculated based on the number of registered businesses by branch of activity, available from IECA, as follows:

$$
I E P_{i j}=\frac{E_{i j}}{E_{j}} / \frac{E_{i}}{E_{t}}
$$

where $E_{i j}$ is the number of registered businesses in sector $i$ of municipality $j, E_{j}$ the total registered businesses of municipality $j, E_{i}$ the total registered businesses in sector $i$ in Andalusia and $E_{t}$ the total registered businesses in this region.

\section{Results and discussion of analysis of cooperative societies compared to mercantile businesses}

\subsection{Exploratory spatial analysis}

Beginning with exploratory spatial analysis, it is first of all worth noting the greater heterogeneity that exists, a priori, in the distribution of cooperativism compared to the more homogeneous behavior shown by mercantile businesses in Andalusia, with both types of organizations considered in relative terms, i.e. out of the total number of businesses (Figure 1). According to the cartograms obtained (Figures 2 and 3 ) in the case of cooperatives there are 38 municipalities with atypical positive values, standing out from the rest of Andalusia, in which the proportion of these societies is highly elevated with respect to the total number of businesses, while in the case of mercantile businesses there are only, based on 2015 data. 


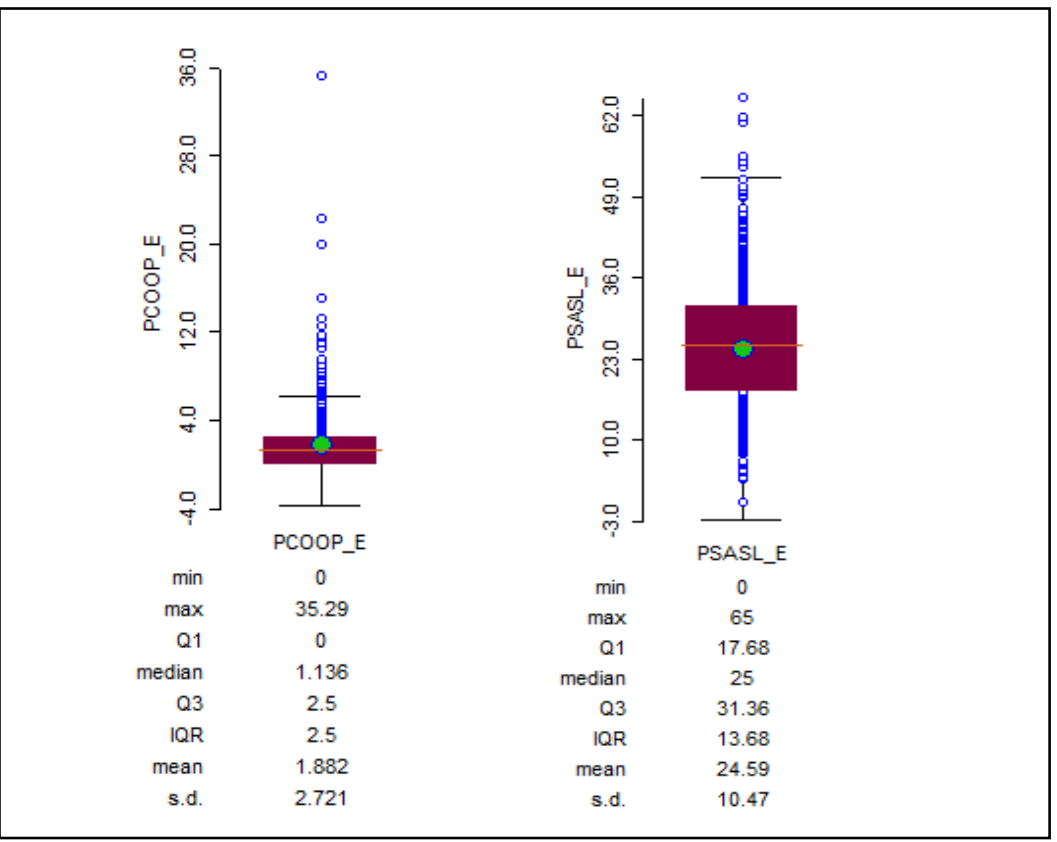

Figure 1. Histograms showing the proportion of cooperatives (left) and the proportion of mercantile businesses (right)

Source: prepared by the authors based on IECA data

These outliers, in addition to being more numerous, show greater intensity in the case of cooperatives than for mercantile businesses, due to the very different values presented by the contiguous municipalities; that is to say, these atypical values, in this case with a highly elevated proportion of cooperatives, are surrounded by low values for this variable. These differences or dissimilarities are not as intense in the case of mercantile businesses, which implies certain patterns of behavior of greater uniformity in Andalusia for these organizations than for cooperatives (Figures 2 and 3).

Moreover, the coefficient of variation shows greater variability or dispersion with respect to the mean value for cooperatives, since this is far greater than that of conventional businesses (1.44 compared to 0.42 respectively). For its part, the mean for the proportion of cooperatives is 13 times lower than that of conventional companies, even though the asymmetry coefficient is positive (4.56), indicating a bias towards the right in its distribution, i.e. the majority of municipalities have a low or null proportion of cooperatives. For the proportion of mercantile businesses, both the asymmetry and the coefficient of kurtosis are very close to 0 , the equal number of values on both sides of the mean signifying that their distribution throughout Andalusia follows a normal pattern of behavior (Table 1).

Table 1. Main statistics

\begin{tabular}{lcc}
\hline & Proportion of cooperative societies (\%) & Proportion of mercantile businesses (\%) \\
\hline Mean & 1.88 & 24.59 \\
\hline Median & 1.14 & 25 \\
\hline Minimum & 0 & 0 \\
\hline Maximum & 35.29 & 65 \\
\hline Standard deviation & 2.72 & 10.47 \\
\hline Coefficient of variation & 1.44 & 0.42 \\
\hline Asymmetry & 4.56 & 0.11 \\
\hline Excess Kurtosis & 37.65 & 0.51 \\
\hline
\end{tabular}

Source: prepared by the authors based on IECA data 
Likewise, in the case of cooperativism, the majority of municipalities (384) have a proportion of cooperatives of between 0 and $1.14 \%$, while in the case of mercantile businesses, the majority is situated in middle values, with 189 localities between $17.7 \%$ and $25 \%$, and 197 between $25 \%$ and $31.4 \%$. Furthermore, as previously indicated, in the case of cooperativism the abnormal elevated values are fare more intense than those for mercantile businesses, owing to the aforementioned observations that the majority of municipalities have low proportions of this type of business (Figures 2 and 3).

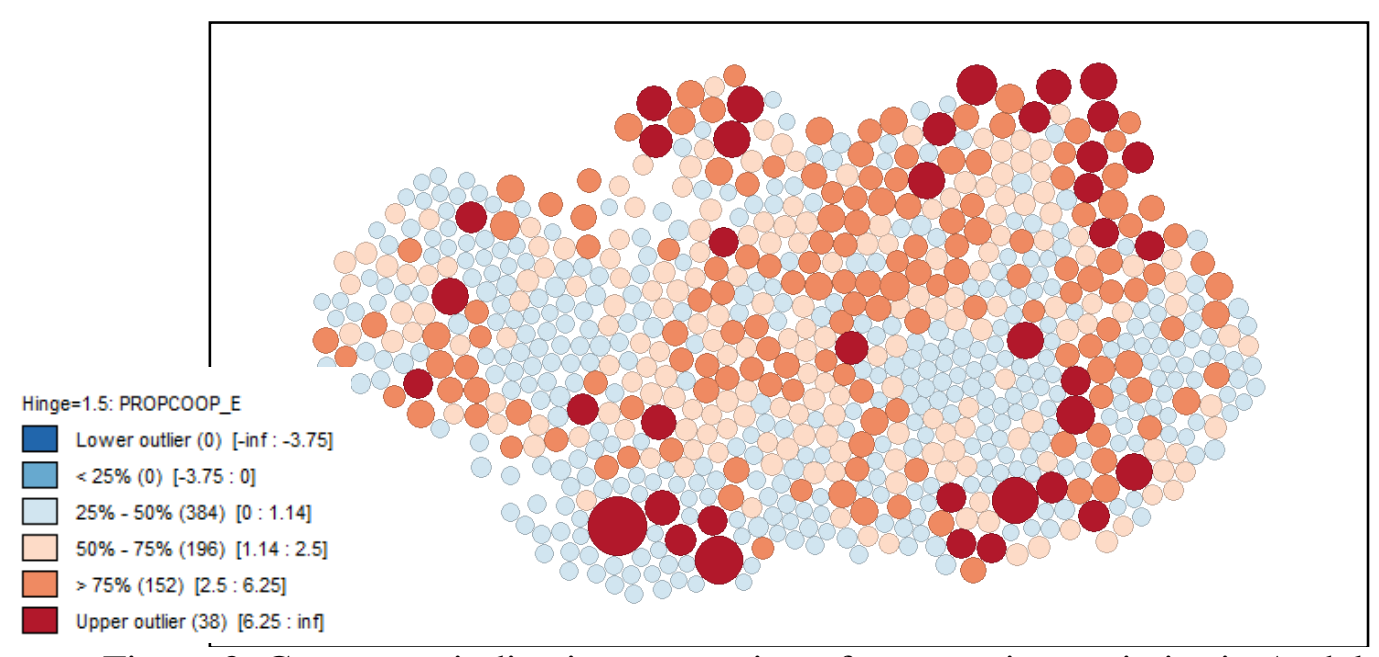

Figure 2. Cartogram indicating proportion of cooperative societies in Andalusia ${ }^{1}$

Source: prepared by the authors based on IECA data

It should also be noted that, given the results obtained in the respective cartograms, the atypical values for cooperatives appears to be concentrated at points in space (as is the case with northern Andalusia), while the outliers in the case of conventional businesses have proven more disperse. This leads to the question of whether the distribution of these businesses follows a pattern of behavior defined by their location in the region or, to the contrary, it is random. This question has been resolved using global and local spatial autocorrelation, the results of which are outlined in the following section.

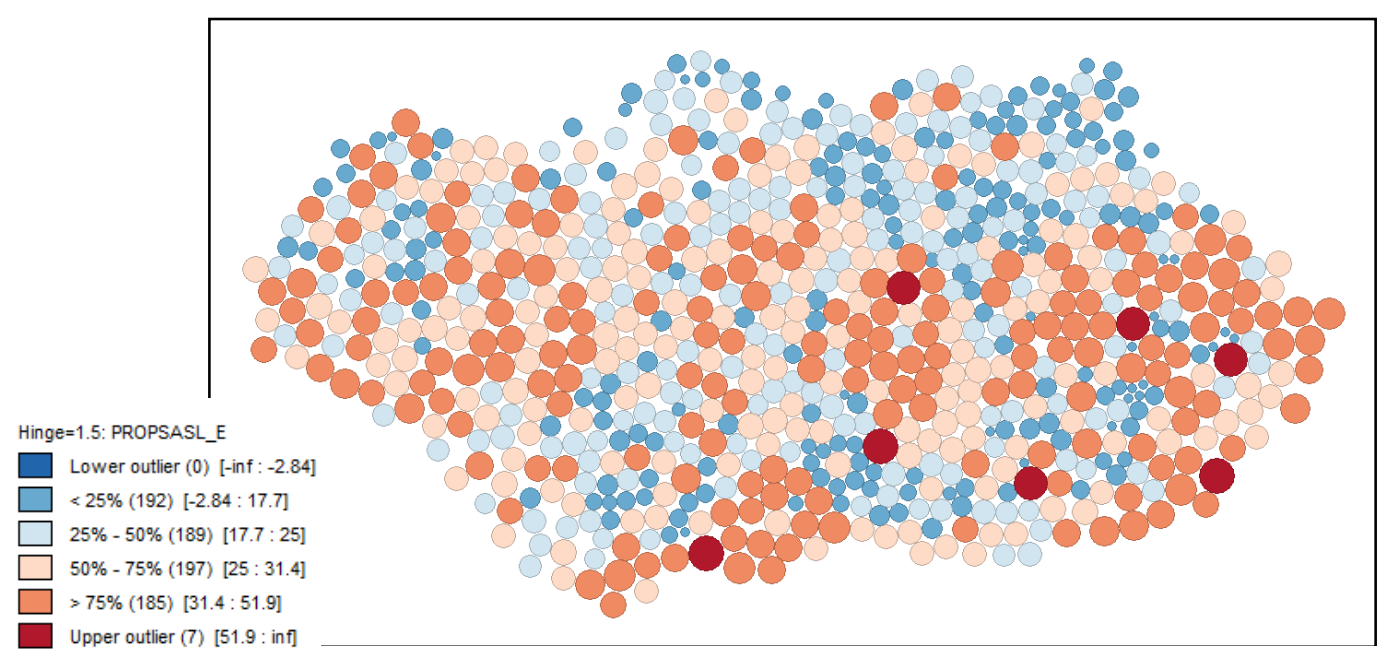

Figure 3. Cartogram indicating proportion of mercantile businesses in Andalusia Source: prepared by the authors based on IECA data

\footnotetext{
${ }^{1}$ The greater the diameter of the circle (which represents a given municipality) the greater the difference between that municipality and contiguous municipalities with respect to the variable under study.
} 


\subsection{Spatial autocorrelations}

The results obtained for the Moran's I applied to the proportion of cooperatives and to the proportion of mercantile businesses show the existence of global spatial autocorrelation in both cases; i.e. the number of businesses (in relative terms) in a given municipality is generally influenced by the number of businesses existing in contiguous municipalities (pseudo p-values associated with standardized values of Moran's I (Z (I)) are less than 0.05, leading to a rejection of the null hypothesis of spatial randomness in the variables under study) (Figures 4 and 5). Moreover, in both cases global autocorrelation is positive, indicating that high (or low) values of the proportion of cooperatives in a given municipality suggests high (or low) values of this same variable in neighboring or contiguous municipalities.

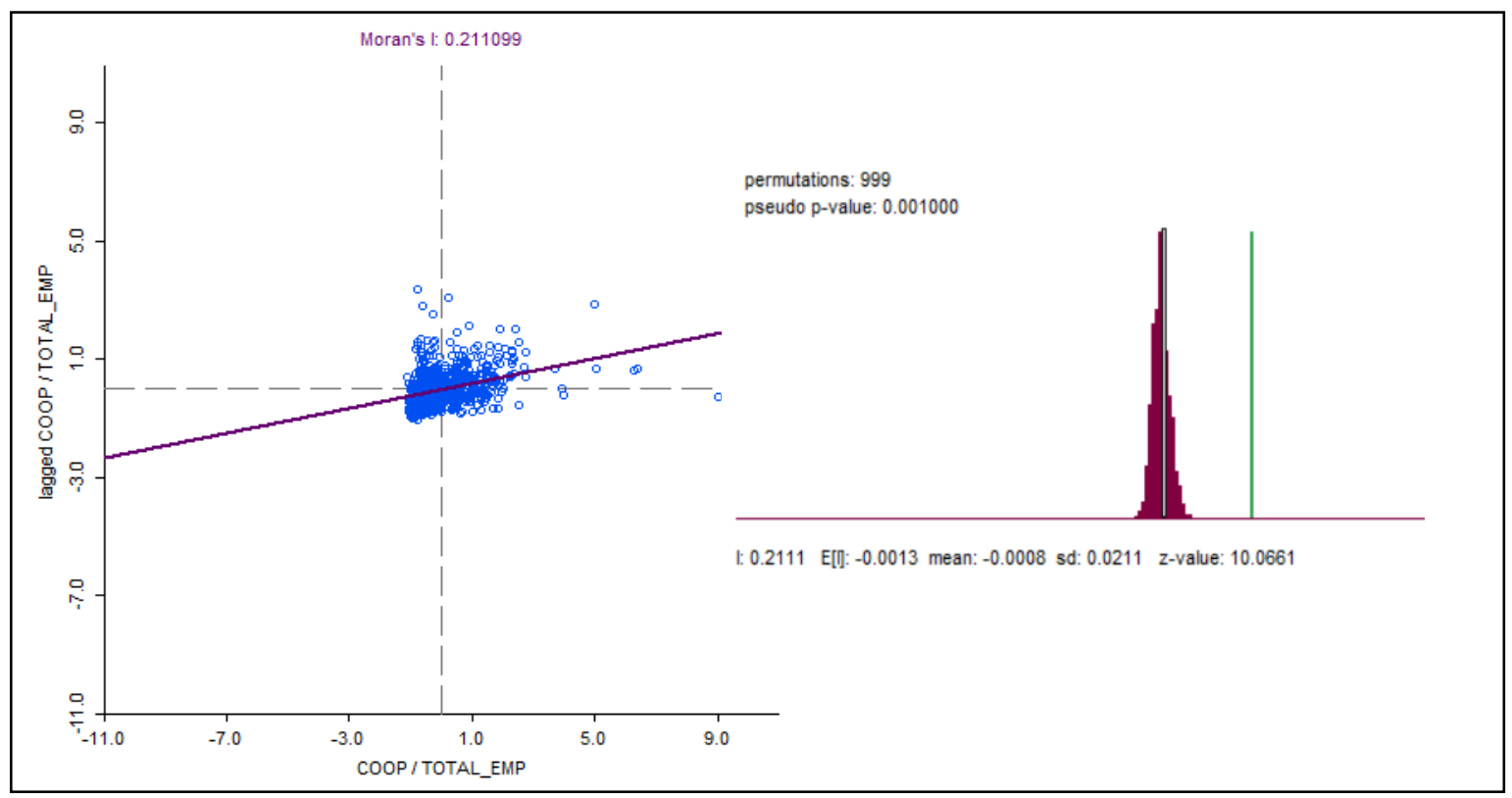

Figure 4. Dispersion diagram of Global Moran's I for cooperatives and significance Source: prepared by the authors based on IECA data

If the Global Moran's I for the proportion of cooperatives is compared with the Moran's I for the proportion of mercantile businesses, it should be noted that the value obtained is greater for the latter ( 0.32 as opposed to 0.21 in the case of cooperatives), which may indicate the existence of greater positive synergies, i.e. that high values for the proportion of mercantile businesses out of the total number of organizations will have an impact on the production of a high proportion of this type of business in neighboring municipalities.

However, what has just been described occurs at a general level, i.e. throughout all of Andalusia. For this reason, and given the territorial diversity existing in the region, LISA has been applied in order to detect spatial groupings or clusters for the behavior of these businesses. The more noteworthy results of these LISA will be discussed below.

For the proportion of cooperatives, spatial autocorrelation does not exist in 583 of the total of 770 municipalities, signifying that it does not respond to a pattern of behavior. There are 43 municipalities with a high proportion of cooperatives surrounded by others which also show high proportions (high-high); in other words, these are environments favoring cooperativism located in the north, particularly in the area of the province of Cordoba, including the municipality of Pozoblanco, home to the COVAP cooperative and which may be generating significant socioeconomic dynamics in the surroundings; northeast Andalusia, including rural municipalities located in the Cazorla mountain range among others; and in certain municipalities in the provinces of Almeria, Granada or Huelva (Figure 6). Of the 43 
municipalities forming part of these environments favoring the business dynamics of cooperatives, it is worth noting that 20 , nearly $50 \%$, are located in the province of Jaen, such that activities related to olive oil, figuring prominently in this province, are possibly driving such a cooperativist environment.

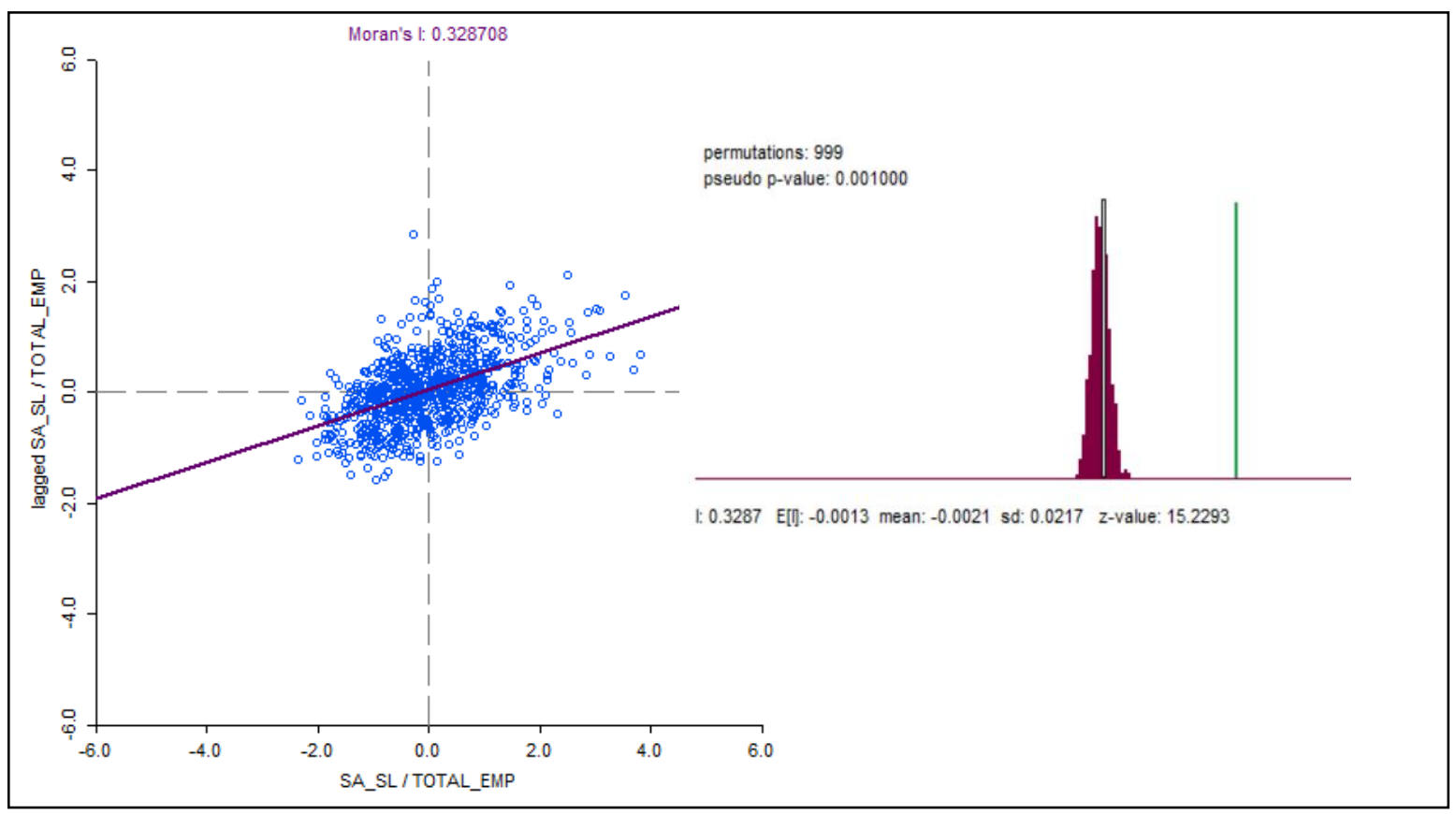

Figure 5. Dispersion diagram of Global Moran's I for mercantile businesses and significance Source: prepared by the authors based on IECA data

With respect to spatial clusters with low cooperativism values (low-low), these are located in the area of the province of Cadiz (coastal and interior), on the Malaga coast, where there is important tourist activity, in municipalities of the province of Seville (mainly in the capital and outskirts) and in municipalities of Huelva, among others (Figure 6). As regards the outliers or negative spatial autocorrelation (low-high and high-low), i.e. in this case municipalities with low values for this variable and surrounded by others with high values or vice versa, there are a total of 37 . This may signify that, despite the existence of certain municipalities with a notable level of cooperativism (outliers), this business culture has not been successfully spread to contiguous areas, possibly owing to a lack of cooperation or support structure on the part of the various local production systems. Nevertheless, this signifies a latent opportunity or potential for the generation of synergies or a dynamic force of attraction towards cooperativism.

For the proportion of mercantile businesses, there is no spatial autocorrelation in 564 municipalities. Positive spatial autocorrelation occurs in 86 municipalities with high values (high-high) and in 90 with low values (low-low). The former are mainly located in coastal municipalities in the provinces of Huelva, Malaga and Almeria, dominated by activities related to the tourism industry; in the vicinity of the capital of Seville, and in municipalities in the interior of the provinces of Almeria, Granada and Cordoba. With respect to low value spatial autocorrelation, this is found in a large portion of Jaen, in the north of Cordoba and in certain municipalities of Malaga's interior and eastern coast, among others. The outliers occur in a total of 30 municipalities, of which 16 are low-high and 14 are high-low (Figure 7). 


\section{INTERDISCIPLINARY APPROACH TO ECONOMICS AND SOCIOLOGY}

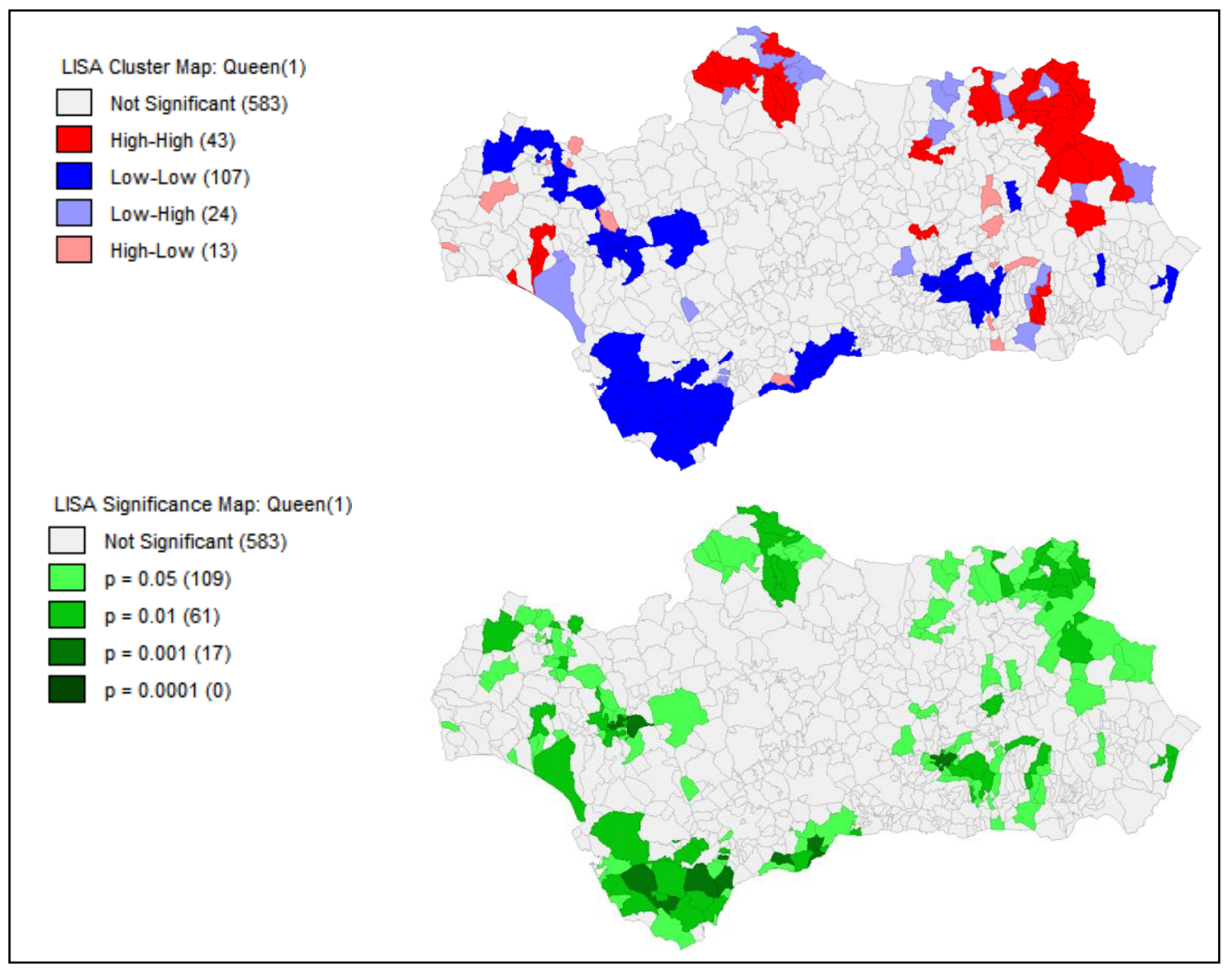

Figure 6. LISA maps of spatial clusters for cooperatives and significance

Source: prepared by the authors based on IECA data

Comparing both results, it should be noted that positive synergies (positive spatial autocorrelation) comprise a greater number of municipalities in the case of mercantile businesses (86), these being double the number of cooperatives (43). This signifies that these dynamic spaces are larger in size in the case of the conventional business sector than in the case of cooperativism (in terms of localities involved). These positive synergies may be indicative of environments having a territorial specificity that is generally favorable to the existence of these businesses, or possible inter-cooperation among these in particular.

Furthermore, the results confirming the existence of outliers or dissimilarities among nearby municipalities may indicate the presence of a certain competition among organizations and/or lack of a support structure among the various municipalities, i.e. the absence of interterritorial cooperation. However, these results must be interpreted cautiously, since the variables used are the number of organizations in relation to the total number of businesses.

Based on the aforementioned, it is worth identifying possible determinants of these environments (spatial agglomerations or clusters) in those for which this ratio of cooperatives is higher. As such, and focusing on these positive synergies, the following question was asked: what do these municipalities belonging to high-high clusters specialize in? In order to respond to this question, the production specialization index (PSI) was calculated for each one, i.e. the degree of specialization for each sector with respect to Andalusia as a whole. 


\section{INTERDISCIPLINARY APPROACH TO ECONOMICS AND SOCIOLOGY}

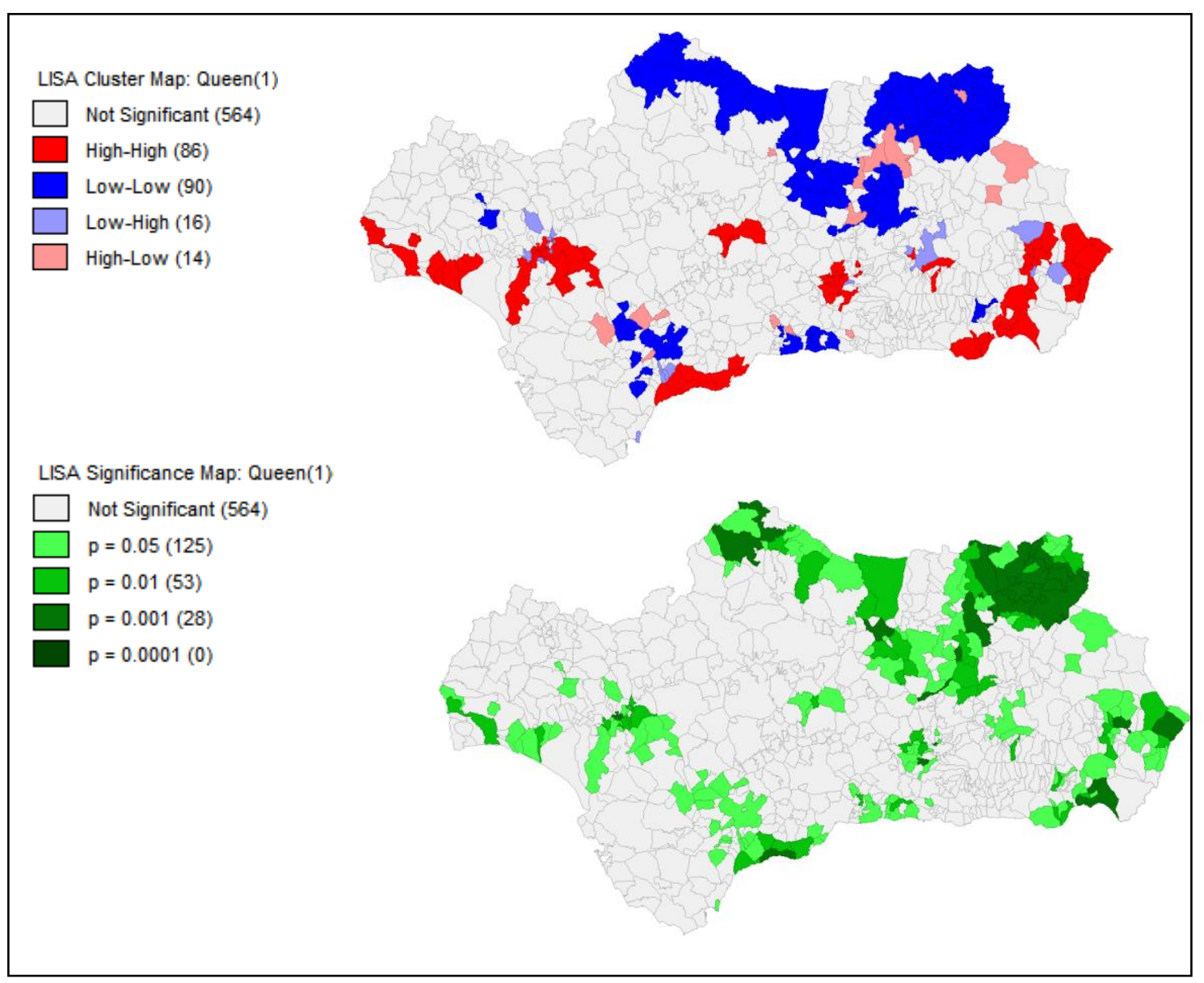

Figure 7. LISA maps of spatial clusters for mercantile businesses and significance Source: prepared by the authors based on IECA data

The results of this specialization index indicate that $95 \%$ of the municipalities in which positive local spatial autocorrelation occurs with respect to the proportion of cooperatives are specialized in the primary sector, while in the case of mercantile businesses the construction sector is prominent, for which $64 \%$ of municipalities have index values greater than one (Table 2). This may be an indication that the cooperativism which prevails in Andalusia is either agricultural in nature or is related to the agriculture sector, while in the case of mercantile businesses the same is true for the construction sector, where this specialization is predominant in two thirds of the municipalities belonging to the high-value cluster.

Table 2. Municipalities belonging to the high-high cluster specializing in various productive sectors (sector PSI > 1)

\begin{tabular}{|c|c|c|c|c|c|c|c|c|c|}
\hline \multirow[b]{2}{*}{ Cluster } & \multicolumn{2}{|l|}{ Primary } & \multicolumn{2}{|l|}{ Industry } & \multicolumn{2}{|c|}{ Construction } & \multicolumn{2}{|l|}{ Services } & \multirow[t]{2}{*}{ Total } \\
\hline & $\begin{array}{c}\text { No. of } \\
\text { municipalities }\end{array}$ & $\%$ & $\begin{array}{c}\text { No. of } \\
\text { municipalities }\end{array}$ & $\%$ & $\begin{array}{c}\text { No. of } \\
\text { municipalities }\end{array}$ & $\%$ & $\begin{array}{c}\text { No. of } \\
\text { municipalities }\end{array}$ & $\%$ & \\
\hline $\begin{array}{l}\text { Proportion of } \\
\text { cooperatives }\end{array}$ & 41 & 95 & 15 & 35 & 19 & 44 & 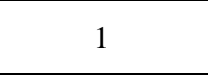 & 2 & 43 \\
\hline $\begin{array}{l}\text { Proportion of } \\
\text { mercantile } \\
\text { businesses }\end{array}$ & 35 & 41 & 35 & 41 & 55 & 64 & 37 & 43 & 86 \\
\hline
\end{tabular}

Source: prepared by the authors based on IECA data

In a sector-by-sector analysis of spatial autocorrelation, the global Moran's I shows values for mercantile businesses that are higher in all sectors, with the exception of industry, where it is higher for cooperatives, (Table 3). Moreover, it has been positive in all cases, 
generally signifying the presence of environments favoring the creation of synergies with the conventional business sector to a greater extent than with cooperativism.

Overall, a notable result is that, for the primary sector, a far higher Moran's I value was obtained for the proportion of mercantile businesses than for cooperatives ( 0.49 and 0.17 respectively).

As the number of agricultural businesses was used as a proxy variable for the primary sector, this result should be interpreted with caution. However, it could be the case that positive spatial autocorrelation for these Social Economy enterprises occurs in areas with a high degree of cooperative activity related to the primary sector, such as the existence of a significant number of agri-food plants (given the previous result for the number of municipalities belonging to the high-value cluster specializing in the primary sector). In fact, the autocorrelation for the industry sector is greater in the case of cooperatives than in that of mercantile businesses and is noteworthy with respect to the values obtained for the rest of economic sectors (Table 3).

Moreover, returning to the high-value cluster obtained in the local autocorrelation for cooperatives, the following should be pointed out: the analysis carried out on the population of these municipalities yields values which are lower with respect to mercantile businesses (Table 4); this may indicate the creation of cooperatives as an alternative in the face of the lack of investment incentives on the part of the conventional business sector in small areas with a low number of inhabitants.

Table 3. Global Moran's I results by sector ${ }^{2}$

\begin{tabular}{ccccc}
\hline & Economic sector & $\begin{array}{c}\text { Moran's } \\
\text { Index }\end{array}$ & Pseudo p-value & $\begin{array}{c}\text { Spatial } \\
\text { autocorrelation }\end{array}$ \\
\hline $\begin{array}{c}\text { Cooperative } \\
\text { societies } / \text { total } \\
\text { businesses }\end{array}$ & Primary & 0.1759 & 0.0010 & Positive \\
\cline { 2 - 4 } & Industry & 0.2735 & 0.0010 & Positive \\
\cline { 2 - 4 } $\begin{array}{c}\text { Mercantile } \\
\text { businesses/total } \\
\text { businesses }\end{array}$ & Construction & 0.0534 & 0.0130 & Positive \\
\cline { 2 - 4 } & Services & 0.1383 & 0.0010 & Positive \\
\cline { 2 - 4 } & Primary & 0.4928 & 0.0010 & Positive \\
\cline { 2 - 4 } & Industry & 0.1909 & 0.0010 & Positive \\
\hline
\end{tabular}

Source: prepared by the authors

In the case of the high-high cluster for the proportion of cooperatives, there are just two municipalities with more than 10,000 inhabitants: Pozoblanco (Cordoba) population 17,380, home to the aforementioned COVAP cooperative and which may have produced a certain consolidating effect on the area's population; and Palos de la Frontera (Huelva) with 10,365 inhabitants. The majority of the municipalities in this cluster $(82 \%)$ do not exceed 5,000 inhabitants (Annex 1). For their part, the municipalities belonging to the high-value cluster for the proportion of mercantile companies have a greater number of inhabitants; although there are some municipalities with lower values, more than $65 \%$ have over 5,000 inhabitants (Annex 2).

An examination of the mean values for population density and the number of inhabitants for these high-value spatial clusters reinforces the differences among those environments yielding positive synergies for cooperativism and for the conventional business sector: for the mercantile company cluster, the average population density is over 665

\footnotetext{
${ }^{2}$ For the primary sector, the total number of agricultural businesses for cooperative societies and mercantile businesses was used as the proxy variable.
} 
inhabitants per square kilometer, while barely reaching 30 for cooperativism; likewise, the average population for the conventional business sector $(29,295$ inhabitants) is 9 times greater than for cooperatives (3,250 inhabitants) (Table 4).

Table 4. Descriptive data for population and population density of municipalities belonging to the high-high cluster

\begin{tabular}{|c|c|c|}
\hline & $\begin{array}{c}\text { Proportion of cooperative societies } \\
\text { (n=43 municipalities })\end{array}$ & $\begin{array}{c}\text { Proportion of mercantile } \\
\text { businesses ( } n=86 \text { municipalities) }\end{array}$ \\
\hline \multicolumn{3}{|l|}{ Populations: } \\
\hline Minimum & 379 & 275 \\
\hline Maximum & 17,380 & 693,878 \\
\hline Mean & $3,250.19$ & $29,295.76$ \\
\hline Standard deviation & $3,408.89$ & $80,961.16$ \\
\hline \multicolumn{3}{|c|}{ Population density (inhabitants/ $\mathrm{km}^{2}$ ): } \\
\hline Minimum & 3.11 & 4.18 \\
\hline Maximum & 210.24 & $7,935.91$ \\
\hline Mean & 29.20 & 665.35 \\
\hline Standard deviation & 40.60 & $1,342.63$ \\
\hline
\end{tabular}

Source: prepared by the authors based on IECA data

The aforementioned may indicate the existence of a larger culture of cooperativism in Andalusia and with positive synergies or inter-cooperation in rural interior localities, especially in the north. This is further confirmed by the observation that no municipalities from coastal regions belong to this high-value cluster, something that does not occur in the case of mercantile businesses.

The above results lead us to consider a number of economic implications, above all when it comes to promoting cooperativism, with respect to the traditional business sector, through public strategies and policies. The maps obtained for municipalities showing negative or positive spatial autocorrelation clearly indicate the need for promotion of Social Economy societies via specific policies, since cooperativism has been shown to have differentiated behavior compared to that of the conventional business sector.

Situating the results of this work with respect to previous studies, it is worth mentioning the study carried out by Chaves et al. (2013) whose findings, after analyzing cooperativism from an international perspective, point to the unequal behavior that it presents in the areas under study, results which are similar to those here in this work. For its part, the work carried out by Cantarero, González-Loureiro and Puig (2017), using the same methodology employed here, and in the case of the Spanish autonomous communities, likewise arrives at the same conclusion: that heterogeneous behavior exists, in this case with regard to the creation of Social Economy Businesses over the 2002-2013 period.

This study is therefore complementary to those preceding it, and further explores the territorial distribution of cooperativism from a spatial analysis, in this case at municipal level in the Spanish region of Andalusia.

\section{Conclusions}

As a final summary of this spatial analysis of cooperatives compared with mercantile businesses in Andalusia the following considerations are of particular interest:

Cooperatives have been shown to behave differently from mercantile businesses, both based on the descriptive spatial analysis, using primary statistics and graphing techniques, and on spatial autocorrelation, with the application of the global and local (LISA maps) Moran's I. 
The descriptive analyses have revealed greater heterogeneity in the distribution of cooperativism (in relative terms) in Andalusia, with a more atypical pattern of behavior than for conventional businesses, with concentrations of a larger number of municipalities with low values for this variable, as opposed to the normal behavior shown by mercantile businesses, the majority of which are found concentrated in middle values.

With respect to the situation of the outliers or atypical values for the cartograms obtained (municipalities having either a significant weight of cooperatives or mercantile businesses, depending on the case), this was found to be different for both types of organizations: the proportion of conventional businesses is more disperse in Andalusia, while the proportion of cooperatives is rather concentrated, appreciably in municipalities in the north of Cordoba and Jaen. These outliers present an opportunity, in the sense that they may produce a positive draw for cooperative culture towards contiguous regions, giving rise to dynamic environments based on these organizations, with their working principles of social and environmental justice and with their strong commitment to the place where they carry out their activities.

With respect to spatial autocorrelation, under the premise that the existence of highvalue (high-high) spatial clusters could signify dynamic spaces for business activity, the presence of positive synergies, the inter-cooperation of businesses or business networks, or the existence of certain socioeconomic and/or territorial factors favoring such a business dynamic, it should be noted that this occurs to a greater extent in the case of mercantile or conventional businesses than with cooperatives, since in the former such spaces are larger in size than in the organizations of Social Economy, in terms of the localities involved (86 and 43 municipalities respectively).

As regards the location of the clusters that unite municipalities belonging to areas with positive dynamics or synergies, i.e. with high values for the proportion of these organizations, two distinct realities should be emphasized:

In the case of the proportion of cooperatives, the high-value clusters are located mainly in the north of Andalusia, of which $95 \%$ are specialized in the farming and livestock sector, possibly indicating that such synergies are produced around these activities. Moreover, these municipalities are small, the majority having less than 5,000 inhabitants. With respect to the proportion of mercantile businesses, these are located not in the north of Andalusia but rather on the coast (provinces of Huelva and Almeria) and in the capital of Seville and its outskirts, among others. As for specialization, although it has been diversified among the different sectors, construction can be considered predominant $(64 \%$ of these municipalities are specialized as such); contrary to what has been observed with cooperativism, only $41 \%$ are specialized in the primary sector.

This invites the consideration that differences exist both in terms of the concentration of cooperativist business dynamics and the conventional business sector in Andalusia and in terms of the socioeconomic characteristics that influence business behavior. In addition, it is important to note that the distribution of cooperativism in Andalusia shows a greater degree of heterogeneity than that of the conventional business sector, thus confirming the hypothesis proposed in this study. For all of these reasons, specific policies and strategies taking regional particularities into account must be put in place in order to promote the stimulus and development of these Social Economy enterprises and bring about greater positive effects in the area. For its part, in the case of mercantile businesses, which have shown a higher degree ofhomogeneity in Andalusia, the application of general regional stimulus policies will bring about greater effects than those focused on cooperativism.

In addition to demonstrating the distinct behavior of such organizations in Andalusia, this study helps to establish an approach to the distribution of cooperative societies in the region. However, it should be noted that this work is not without its limitations: a static 
analysis has been carried out, for a given moment in time (2015), supposing a limitation when it comes to analyzing the evolutionary tendency followed by these organizations. However, this analysis allows for an understanding of the sector and the roll it plays in the territorial dynamics of Andalusia, something not undertaken to date and which highlights the importance of one of the contributions made by this research.

At the same time, this study constitutes a base for continuing research on cooperativism in Andalusia, opening new lines of investigation geared towards determining the factors fostering the emergence of cooperative societies. Given that the most favorable environments for these societies have been identified (as well as those least favorable to Social Economy enterprises) it would be worthwhile identifying not only those factors having a positive influence but also those which represent a limitation to the development of such businesses, for the purpose of applying specific measures for their stimulus. An analysis should likewise be undertaken as to the type of cooperativism which is predominant in each region, in order to design and apply specific policies in accordance with these organizations and with the real territorial circumstances, such that cooperative businesses are able to respond to a greater extent to the needs of the area in which they are operative.

This study thus provides a deeper understanding of the business sector in general and of cooperativism in particular in the autonomous community of Andalusia, a determining factor in the planning and implementation of territorial policies and in their impact on the sustainable development of the most socially and economically disadvantaged regions of Spain.

\section{References}

Amara, M. (2009). Concentration et agglomération industrielles dans la métropole de Tunis. Revue d'Économie Régionale \& Urbaine, 3, 599-624.

Anselin, L. (1988). Spatial Econometrics: Methods and Models. Dordrech: Kluwer.

Anselin, L. (1995). Local indicators of spatial association -LISA-. Geographical analysis, 27(2), 93115.

Anselin, L. (1998). Exploratory Spatial Data Analysis in a Geocomputational Environment. Regional Research Institute and Department of Economics. West Virginia University. Actas de la conferencia de Geo Computación 1998, Bristol (UK).

Buendía, I., \& García J. V. (2003). Cooperativismo y desarrollo local. Madrid: Editorial Centro de Estudios Ramón Areces.

Burgués, A., Martin, S., \& Santa Cruz, I. (2013). La relación entre cooperativas transformadoras y desigualdades sociales en los territorios. Scripta Nova, Revista Electrónica de Geografía y Ciencias Sociales, 427 (4). DOI: http://dx.doi.org/10.1344/sn2013.17.14911

Calvo, R., \& González, J. (2011). La creación de empresas de economía social en el modelo de desarrollo local: reflexiones sobre la divergencia actual del caso valenciano. REVESCO, Revista de Estudios Cooperativos, 104, 7-37.

Cantarero, S., González-Loureiro, M., \& Puig, F. (2017). Efectos de la crisis económica sobre el emprendimiento en empresas de economía social en España: un análisis espacial. REVESCO. Revista de Estudios Cooperativos, 125, 24-48.

Caravaca, I., González, G., \& Mendoza, A. (2007). Indicadores de dinamismo, innovación y desarrollo: su aplicación en ciudades pequeñas y medias de Andalucía. Boletín de la Asociación de Geógrafos Españoles, 43, 131-154.

Chaves, R., Monzón, J.L, Pérez de Uralde, J.M., \& Radrigán, M. (2013). La economía social en clave internacional. Cuantificación, reconocimiento institucional y visibilidad social en Europa, Iberoamérica y norte de África. REVESCO. Revista de Estudios Cooperativos, 112, 122-150.

Cliff, A. D. \& Ord, J. K. (1981). Spatial processes: models\& applications (Vol. 44). London: Pion.

Colletis, G., Gianfaldoni, P. \& Richez-Battesti, N. (2005). Économie sociale et solidaire, territoires et proximité. Revue internationale de l'économie sociale: Recma, 296, 8-25. 
Coque, J. (2005). Compartir soluciones: las cooperativas como factor de desarrollo en zonas desfavorecidas. Madrid: Consejo Económico y Social.

Cuñat, R., \& Coll, V. (2007). ¿Contribuyen las cooperativas de reciente creación al desarrollo local? Una visión desde los principios cooperativistas. Revista Venezolana de Economía Social, 13, 829.

Demoustier, D. (2011). Les concepts philosophiques et sociaux de l'ESS dans ses rapports à l'activité économique et aux territoires. In A. Ndiaye (dir.), Économie sociale et solidaire: animation et dynamiques des territoires (pp. 47-60). Paris: L'Harmattan.

Draperi, J.F. (2014). Comprendre l'économie sociale. Fondements et enjeux. Paris: Dunod.

Fernández, A., Mendoza, A., Pedregal, B., \& Zoido, F. (2007). Relaciones entre cohesión, diversidad $y$ desarrollo territorial. Aplicaciones en Andalucía. La Geografía en la frontera de los conocimientos, XX Congreso de Geógrafos Españoles, Sevilla.

García-Gutiérrez, C. (1999). Cooperativismo y desarrollo local. REVESCO, Revista de Estudios Cooperativos, 68, 33-46.

Goodchild, M. (1987). A spatial analytical perspective on geographical information systems. International Journal of Geographical Information System, 1, 327-334.

Guzmán, C., Santos, F.J., \& Barroso, M. (2016). Cooperativismo, factor empresarial y desarrollo económico: propuesta de un modelo teórico de enlace. REVESCO, Revista de Estudios Cooperativos, 122, 110-134

Longley, P., \& Tobon, C. (2004). Spatial dependence and heterogeneity in patterns of hardship: an intra-urban analysis. Annals of the Association of American Geographers, 94(3), 503-519.

Méndez, R., Melero, A., \& Calatrava, A. (2008). Desarrollo territorial policéntrico y ciudades intermedias: recursos productivos y dinámicas económicas locales en Andalucía. Estudios Geográficos, 69(265), 637-663.

Moreno, R., \& Vayá, E. (2000). Técnicas econométricas para el tratamiento de datos espaciales: La Econometría Espacial. Barcelona: Ediciones de la Universidad de Barcelona.

Mozas, A., \& Bernal, E. (2006). Desarrollo territorial y economía social. CIRIEC-España, Revista de Economía Pública, Social y Cooperativa, 55, 125-140.

Novkovic, S. (2008). Defining the co-operative difference. The Journal of Socio-Economics, vol. 37, $\mathrm{n}^{\mathrm{o}} 6,2168-2177$.

Pérez, M.C., \& Valiente, L. (2017). La localización sectorial del cooperativismo: una aproximación a nivel territorial español. REVESCO, Revista de Estudios Cooperativos, 123, 198-224.

Pita, M.F., \& Pedregal, B. (Coords.) (2011). Tercer Informe de Desarrollo Territorial de Andalucía. Sevilla. Secretariado de Publicaciones de la Universidad de Sevilla. Disponible en http://grupo.us.es/giest/ (Accessed 3 February 2018).

Puentes, R., \& Velasco, M. (2009). Importancia de las sociedades cooperativas como medio para contribuir al desarrollo económico, social y medioambiental, de forma sostenible y responsable. REVESCO, Revista de Estudios Cooperativos, 99, 104-129.

Sánchez, P., Gallardo, R., \& Ceña, F. (2014). El medio rural andaluz frente a la crisis económica: un análisis de los factores de resiliencia territorial. Economía Agraria y Recursos Naturales, 14(1), 27-56.

Torres, F.J., \& Ojeda, J.F. (2004). Pobreza en Andalucía. SEMATA, Ciencias Sociais e Humanidades, 16, 79-99.

Vilallonga, A. (2002). Los nuevos yacimientos de empleo: una oportunidad para crear empleo y satisfacer nuevas necesidades sociales. Scripta Nova, Revista Electrónica de Geografía y Ciencias, v. 6, $\mathrm{n}^{\circ} 119$.

Zoido, F., Pedregal, B., Pita, M.F., Torres, F.J., \& Fernández-Tabales, A. (2009). Medición del desarrollo territorial en las escalas de detalle. Aplicación a Andalucía. In J. Farinós, J. Romero y J. Salom (eds.), Cohesión e inteligencia territorial. Dinámicas y procesos para una mejor planificación y toma de decisiones (pp. 245-265).Valencia: Publicaciones de la Universitat de Valencia. 
INTERDISCIPLINARY APPROACH TO ECONOMICS AND SOCIOLOGY

ANNEX 1. MUNICIPALITIES BELONGING TO THE HIGH-HIGH CLUSTER, PROPORTION OF COOPERATIVES

\begin{tabular}{|c|c|c|c|c|c|c|c|}
\hline \multirow[b]{2}{*}{ Province } & \multirow[b]{2}{*}{ Municipality } & \multicolumn{4}{|c|}{ Productive specialization indices } & \multirow{2}{*}{$\begin{array}{c}\text { Population } \\
\text { density } \\
\left(\text { pop } / \mathrm{km}^{2}\right)\end{array}$} & \multirow{2}{*}{$\begin{array}{c}\text { Total } \\
\text { population }\end{array}$} \\
\hline & & Agriculture & Industry & Construction & Services & & \\
\hline \multirow{4}{*}{ Almeria } & Abrucena & 1.58 & 1.0633 & 5.4136 & 0.5337 & 15.28 & 1279 \\
\hline & Fondon & 1.0198 & 3.285 & 0.9383 & 0.7087 & 11.18 & 1020 \\
\hline & Laujar de Andarax & 0.5688 & 0.9559 & 2.404 & 0.9849 & 16.96 & 1574 \\
\hline & Maria & 3.0922 & 2.4911 & 0.8464 & 0.4361 & 5.7 & 1285 \\
\hline \multirow{10}{*}{ Cordoba } & Alcaracejos & 1.9629 & 0.6323 & 1.1287 & 0.8467 & 8.67 & 1523 \\
\hline & Añora & 2.6994 & 0.8724 & 1.6716 & 0.6403 & 13.88 & 1563 \\
\hline & Blazquez (Los) & 2.2137 & 0 & 1.6393 & 0.7557 & 6.84 & 703 \\
\hline & Dos Torres & 2.1895 & 1.3841 & 2.4118 & 0.62 & 19.03 & 2457 \\
\hline & Granjuela (La) & 3.7795 & 0 & 1.6691 & 0.4493 & 8.58 & 482 \\
\hline & Hinojosa del Duque & 1.2319 & 1.5208 & 2.2628 & 0.8082 & 13.27 & 7054 \\
\hline & Pozoblanco & 1.111 & 2.4945 & 1.0788 & 0.8043 & 52.68 & 17380 \\
\hline & Santa Eufemia & 2.4875 & 1.1832 & 1.0364 & 0.6569 & 4.59 & 859 \\
\hline & Valsequillo & 3.3303 & 0 & 1.4363 & 0.5387 & 3.11 & 379 \\
\hline & Villaralto & 1.6849 & 1.3485 & 1.661 & 0.7538 & 51.37 & 1238 \\
\hline \multirow{5}{*}{ Granada } & Castril & 2.2259 & 0.9759 & 2.3507 & 0.6717 & 9.35 & 2276 \\
\hline & Cullar & 1.2914 & 1.921 & 1.8785 & 0.7745 & 10.17 & 4351 \\
\hline & Huescar & 1.0934 & 1.1662 & 2.0024 & 0.891 & 16.21 & 7677 \\
\hline & Montillana & 6.1874 & 0.3226 & 0 & 0.1429 & 17.69 & 1330 \\
\hline & $\begin{array}{c}\text { Puebla de Don } \\
\text { Fadrique }\end{array}$ & 2.7935 & 0.9284 & 1.9603 & 0.587 & 4.45 & 2329 \\
\hline \multirow{4}{*}{ Huelva } & Bonares & 4.0829 & 0.4414 & 0.5781 & 0.5017 & 93.4 & 6090 \\
\hline & Lucena del Puerto & 5.9457 & 0.027 & 0.4163 & 0.2012 & 43.95 & 3046 \\
\hline & Niebla & 0.5859 & 1.1963 & 0.6282 & 1.0825 & 17.88 & 3999 \\
\hline & Palos de la Frontera & 1.7407 & 4.0386 & 1.0209 & 0.5114 & 210.24 & 10365 \\
\hline \multirow{20}{*}{ Jaén } & Beas de Segura & 5.7115 & 0.4003 & 0.2432 & 0.2183 & 34.12 & 5439 \\
\hline & Begijar & 4.9804 & 0.5932 & 0.411 & 0.3257 & 73.2 & 3133 \\
\hline & Benatae & 4.2213 & 0.6524 & 0 & 0.4558 & 10.94 & 487 \\
\hline & Chiclana de Segura & 6.5025 & 0 & 0.1262 & 0.1038 & 4.33 & 1023 \\
\hline & Frailes & 4.3996 & 1.5723 & 0.663 & 0.303 & 40.97 & 1651 \\
\hline & Genave & 5.3568 & 0.3893 & 0.3996 & 0.2387 & 9.72 & 618 \\
\hline & Hornos & 5.6127 & 0 & 0 & 0.2426 & 5.59 & 657 \\
\hline & Jabalquinto & 6.1487 & 0.4663 & 0.3027 & 0.1163 & 30.07 & 2201 \\
\hline & Mengíbar & 1.0928 & 2.3408 & 1.3802 & 0.8025 & 159.47 & 9935 \\
\hline & Navas de San Juan & 6.0943 & 0.387 & 0.1782 & 0.1514 & 26.8 & 4712 \\
\hline & Orcera & 3.0897 & 1.5175 & 0.7788 & 0.5518 & 15.21 & 1919 \\
\hline & $\begin{array}{l}\text { Santisteban del } \\
\text { Puerto }\end{array}$ & 5.3334 & 0.6034 & 0.4439 & 0.2546 & 12.51 & 4666 \\
\hline & Segura de la Sierra & 4.4865 & 0.5496 & 0.6138 & 0.3937 & 8.52 & 1916 \\
\hline & Siles & 3.797 & 0.4478 & 1.3238 & 0.493 & 13.18 & 2345 \\
\hline & $\begin{array}{c}\text { Sorihuela del } \\
\text { Guadalimar }\end{array}$ & 5.7652 & 0.2225 & 0 & 0.2285 & 22.57 & 1248 \\
\hline & $\begin{array}{c}\text { Torres de } \\
\text { Albanchez } \\
\end{array}$ & 5.3924 & 0.7178 & 0.8105 & 0.1791 & 15.15 & 877 \\
\hline & $\begin{array}{c}\text { Villanueva del } \\
\text { Arzobispo }\end{array}$ & 5.5732 & 0.6266 & 0.3293 & 0.2134 & 47.72 & 8484 \\
\hline & Villarrodrigo & 4.8703 & 0.478 & 0 & 0.3749 & 5.58 & 438 \\
\hline & Villatorres & 5.8458 & 0.6185 & 0.3326 & 0.1592 & 60.69 & 4412 \\
\hline & Santiago-Pontones & 3.0557 & 0.9244 & 0.5904 & 0.6415 & 4.89 & 3338 \\
\hline
\end{tabular}

Source: prepared by the authors 
INTERDISCIPLINARY APPROACH TO ECONOMICS AND SOCIOLOGY

ANNEX 2. MUNICIPALITIES BELONGING TO THE HIGH-HIGH CLUSTER, PROPORTION OF DE MERCANTILE BUSINESSES

\begin{tabular}{|c|c|c|c|c|c|c|c|}
\hline \multirow[b]{2}{*}{ Province } & \multirow[b]{2}{*}{ Municipality } & \multicolumn{4}{|c|}{ Productive specialization indices } & \multirow{2}{*}{$\begin{array}{c}\text { Population } \\
\text { density } \\
\left(\text { pop } / \mathrm{km}^{2}\right)\end{array}$} & \multirow{2}{*}{$\begin{array}{c}\text { Total } \\
\text { population }\end{array}$} \\
\hline & & Agriculture & Industry & Construction & Services & & \\
\hline \multirow{29}{*}{ Almeria } & Albox & 0.1619 & 1.7078 & 1.3019 & 1.0605 & 67.87 & 11429 \\
\hline & Almeria & 0.6313 & 0.2449 & 0.624 & 1.1844 & 655.65 & 194203 \\
\hline & Antas & 1.6655 & 0.418 & 2.0657 & 0.8659 & 32.24 & 3195 \\
\hline & Benahadux & 0.2148 & 2.3541 & 1.8558 & 0.9274 & 251.99 & 4183 \\
\hline & Cantoria & 0.3573 & 3.7325 & 1.1022 & 0.8032 & 45.32 & 3580 \\
\hline & $\begin{array}{l}\text { Cuevas del } \\
\text { Almanzora } \\
\end{array}$ & 3.1226 & 0.7509 & 1.3746 & 0.5969 & 50.2 & 13292 \\
\hline & Chercos & 1.2567 & 1.8103 & 0 & 0.7916 & 20.52 & 275 \\
\hline & Fines & 0.2762 & 4.1777 & 2.3233 & 0.6732 & 92.77 & 2143 \\
\hline & Gador & 0.848 & 4.5822 & 0.3259 & 0.6647 & 34.52 & 3027 \\
\hline & Gallardos (Los) & 1.2361 & 0.3759 & 3.2818 & 0.8554 & 85.19 & 2973 \\
\hline & Garrucha & 0.4345 & 0.4612 & 1.6286 & 1.1242 & 1113.9 & 8577 \\
\hline & Huercal de Almería & 0.1024 & 1.069 & 1.519 & 1.1297 & 804.93 & 16823 \\
\hline & Huercal-Overa & 1.0154 & 0.7391 & 1.1801 & 1.0158 & 58.33 & 18530 \\
\hline & Lijar & 0 & 0 & 4.4495 & 0.8148 & 15.34 & 431 \\
\hline & Macael & 0.022 & 8.7807 & 0.4487 & 0.3392 & 129.59 & 5676 \\
\hline & Mojacar & 0.1974 & 0.3185 & 1.2749 & 1.214 & 95.45 & 6825 \\
\hline & Oluladel Rio & 0.0369 & 2.4179 & 1.7649 & 0.9666 & 266.34 & 6259 \\
\hline & Partaloa & 0 & 0.9823 & 1.8438 & 1.0566 & 12.79 & 673 \\
\hline & Pechina & 2.89 & 0.922 & 1.5954 & 0.5973 & 83.73 & 3860 \\
\hline & Pulpi & 3.7908 & 0.5191 & 0.9767 & 0.5229 & 92.52 & 8762 \\
\hline & Roquetas de Mar & 1.8719 & 0.3687 & 1.0314 & 0.9042 & 1517.97 & 90623 \\
\hline & Tabernas & 0.4814 & 1.635 & 0.6644 & 1.0441 & 13.08 & 3668 \\
\hline & Tahal & 5.4957 & 0 & 0.6068 & 0.2318 & 4.18 & 396 \\
\hline & Turre & 0.1871 & 0.4353 & 3.1379 & 1.065 & 30.98 & 3346 \\
\hline & Vera & 0.537 & 0.569 & 1.6203 & 1.0963 & 260.48 & 15108 \\
\hline & Viator & 0.2418 & 0.7634 & 1.3259 & 1.15 & 276.6 & 5698 \\
\hline & Vícar & 2.7762 & 0.5443 & 0.8083 & 0.7262 & 382.13 & 24571 \\
\hline & Ejido (El) & 2.8141 & 0.4957 & 0.4453 & 0.7497 & 380.7 & 85961 \\
\hline & Mojonera (La) & 4.2674 & 0.5853 & 0.3479 & 0.4666 & 375.02 & 8963 \\
\hline \multirow{4}{*}{ Cordoba } & $\begin{array}{l}\text { Aguilar de la } \\
\text { Frontera }\end{array}$ & 3.508 & 0.8635 & 0.9341 & 0.5372 & 81.39 & 13551 \\
\hline & Cabra & 2.9774 & 0.9303 & 0.7101 & 0.6505 & 90.95 & 20837 \\
\hline & Monturque & 3.673 & 3.2045 & 0.9341 & 0.2405 & 61.19 & 2007 \\
\hline & Moriles & 2.5339 & 1.4457 & 1.6259 & 0.6113 & 197.33 & 3848 \\
\hline \multirow{16}{*}{ Granada } & Alhendin & 0.1782 & 1.6639 & 1.3663 & 1.0515 & 167.38 & 8503 \\
\hline & Calicasas & 3.8096 & 0 & 2.6986 & 0.4331 & 53.63 & 606 \\
\hline & Cijuela & 1.236 & 1.4956 & 1.2964 & 0.872 & 179.94 & 3221 \\
\hline & Chauchina & 0.5841 & 0.9211 & 1.6784 & 1.0385 & 256.04 & 5428 \\
\hline & Chimeneas & 5.2661 & 0.3772 & 0.7846 & 0.2581 & 15.06 & 1360 \\
\hline & Ferreira & 1.9748 & 1.8103 & 0 & 0.7228 & 7.2 & 314 \\
\hline & Fuente Vaqueros & 1.2917 & 1.8853 & 1.642 & 0.7951 & 278.56 & 4457 \\
\hline & Lachar & 1.4243 & 2.1345 & 1.8346 & 0.7236 & 249.08 & 3263 \\
\hline & Malaha (La) & 0.3971 & 2.614 & 2.6489 & 0.7613 & 72.2 & 1834 \\
\hline & Maracena & 0.0777 & 1.1887 & 1.5516 & 1.1185 & 4452.24 & 21816 \\
\hline & Pinos Puente & 2.4524 & 1.5482 & 0.7723 & 0.6745 & 114.16 & 10605 \\
\hline & Pulianas & 0 & 1.7375 & 0.7922 & 1.1213 & 851.75 & 5366 \\
\hline & Purullena & 0.2432 & 6.8965 & 0.7882 & 0.4765 & 113.16 & 2399 \\
\hline & Santa Fe & 0.5091 & 2.3634 & 1.2196 & 0.9248 & 394.42 & 15067 \\
\hline & Ventas de Huelma & 2.6929 & 2.1623 & 2.0647 & 0.4589 & 15.59 & 661 \\
\hline & Valle del Zalabi & 1.4314 & 2.7265 & 2.2389 & 0.6312 & 20.51 & 2229 \\
\hline \multirow{10}{*}{ Huelva } & Bonares & 4.0829 & 0.4414 & 0.5781 & 0.5017 & 93.4 & 6090 \\
\hline & Cartaya & 2.6083 & 0.28 & 0.8949 & 0.7826 & 85.06 & 19164 \\
\hline & Granado (El) & 1.5958 & 0 & 3.4258 & 0.7819 & 5.53 & 540 \\
\hline & Huelva & 0.0943 & 0.6936 & 0.771 & 1.226 & 967.07 & 146318 \\
\hline & Lucena del Puerto & 5.9457 & 0.027 & 0.4163 & 0.2012 & 43.95 & 3046 \\
\hline & Moguer & 4.2536 & 0.3679 & 0.9443 & 0.4537 & 105.08 & 21383 \\
\hline & Palos de la Frontera & 1.7407 & 4.0386 & 1.0209 & 0.5114 & 210.24 & 10365 \\
\hline & $\begin{array}{c}\text { Rociana del } \\
\text { Condado }\end{array}$ & 3.3035 & 0.4561 & 1.5701 & 0.5813 & 106.15 & 7643 \\
\hline & $\begin{array}{c}\text { San Bartolome de } \\
\text { la Torre }\end{array}$ & 3.4989 & 1.7641 & 0.8968 & 0.4376 & 63.75 & 3608 \\
\hline & $\begin{array}{c}\text { Sanlucar de } \\
\text { Guadiana } \\
\end{array}$ & 1.9235 & 0 & 4.2473 & 0.6392 & 4.59 & 443 \\
\hline
\end{tabular}


INTERDISCIPLINARY APPROACH TO ECONOMICS AND SOCIOLOGY

\begin{tabular}{|c|c|c|c|c|c|c|c|}
\hline \multirow{9}{*}{ Malaga } & $\begin{array}{c}\text { Alhaurin de la } \\
\text { Torre }\end{array}$ & 0.4209 & 0.6651 & 1.8925 & 1.0887 & 465.82 & 38523 \\
\hline & Benahavis & 0.0892 & 0.096 & 2.9258 & 1.1455 & 48.83 & 7105 \\
\hline & Benalmadena & 0.0207 & 0.302 & 0.9573 & 1.2718 & 2475.76 & 66598 \\
\hline & Estepona & 0.0983 & 0.3254 & 2.7506 & 1.1297 & 487.85 & 67080 \\
\hline & Istan & 0.2596 & 0 & 2.1492 & 1.1114 & 13.98 & 1388 \\
\hline & Marbella & 0.0276 & 0.458 & 1.6673 & 1.2034 & 1194.67 & 139537 \\
\hline & Mijas & 0.0394 & 0.4305 & 1.9847 & 1.1822 & 534.16 & 79483 \\
\hline & Ojen & 0.1335 & 0.5985 & 3.3171 & 1.0383 & 39.03 & 3353 \\
\hline & Torremolinos & 0.0076 & 0.3887 & 0.9732 & 1.2634 & 3391.56 & 67492 \\
\hline \multirow{18}{*}{ Seville } & Alcala de Guadaira & 0.1175 & 3.0256 & 1.6966 & 0.8912 & 262.98 & 74845 \\
\hline & Aznalcazar & 2.1825 & 2.1754 & 0.7601 & 0.6508 & 9.94 & 4469 \\
\hline & $\begin{array}{l}\text { Bollullos de la } \\
\text { Mitacion }\end{array}$ & 0.4711 & 0.5621 & 0.9051 & 1.1588 & 163.45 & 10199 \\
\hline & Bormujos & 0.0572 & 0.3561 & 1.0843 & 1.2487 & 1750.98 & 21362 \\
\hline & $\begin{array}{c}\text { Castilleja de la } \\
\text { Cuesta }\end{array}$ & 0 & 0.3611 & 0.8715 & 1.2733 & 7935.91 & 17459 \\
\hline & Dos Hermanas & 0.0796 & 1.4381 & 1.1582 & 1.117 & 818.17 & 131317 \\
\hline & Espartinas & 0.1353 & 0.3554 & 1.0039 & 1.2395 & 656.78 & 14909 \\
\hline & Gelves & 0.0864 & 0.7846 & 1.7816 & 1.1469 & 1199.76 & 9838 \\
\hline & Gines & 0.0222 & 0.7776 & 1.7494 & 1.1623 & 4589.31 & 13309 \\
\hline & Mairena del Alcor & 0.578 & 1.9223 & 2.6812 & 0.8604 & 326.38 & 22749 \\
\hline & $\begin{array}{c}\text { Mairena del } \\
\text { Aljarafe }\end{array}$ & 0.024 & 0.4478 & 1.0008 & 1.2515 & 2507.8 & 44388 \\
\hline & Molares (Los) & 0.6923 & 1.8936 & 3.6344 & 0.7495 & 81.19 & 3467 \\
\hline & $\begin{array}{c}\text { Palacios y } \\
\text { Villafranca (Los) }\end{array}$ & 0.7111 & 1.1674 & 1.815 & 0.9812 & 348.47 & 38157 \\
\hline & Palomares del Río & 0.0883 & 0.6826 & 2.4045 & 1.1149 & 631.62 & 8211 \\
\hline & Sevilla & 0.0408 & 0.7313 & 0.6687 & 1.2391 & 4910.67 & 693878 \\
\hline & Tomares & 0.03 & 0.6474 & 0.7883 & 1.2424 & 4758.27 & 24743 \\
\hline & Umbrete & 0.7437 & 1.8211 & 1.2211 & 0.9416 & 694.03 & 8606 \\
\hline & $\begin{array}{l}\text { Valencina de la } \\
\text { Concepcion }\end{array}$ & 0.0658 & 1.8678 & 1.0074 & 1.0811 & 316.65 & 7948 \\
\hline
\end{tabular}

Source: prepared by the authors 